\title{
Economic Feasibility of Biofuel Crops in Florida: Energycane on Mineral Soils ${ }^{1}$
}

\author{
José Álvarez and Zane R. Helsel ${ }^{2}$
}

\section{Introduction}

Florida has caught the attention of several firms that have developed technologies to convert crop biomass into energy. Many proponents of renewable energy see a comparative advantage in the "Sunshine State" in terms of energy crop production. University of Florida's Institute of Food and Agricultural Sciences (UF/IFAS) is currently involved in a multitude of research projects in this area under the leadership of the Florida Institute for Sustainable Energy (http://www.energy.ufl.edu).

Florida sugarcane producers and processors have accumulated nearly a century of experience with growing sugarcane for processing and refining into sugar. Although there has been interest relative to harvesting the crop for energy, early evaluations have been limited to field experiments at the Everglades Research and Education Center (EREC), funded by the Battelle Institute in the 1980s, and some variety work under the joint plant germplasm development program between the University of Florida's Institute of Food and Agricultural Sciences (UF/IFAS) and the United States Department of Agriculture's Agricultural Research Service
(USDA/ARS) at the U.S. Sugarcane Field Station at Canal Point, Florida.

The purpose of this fact sheet is to explore the economic feasibility of growing "energycane" as a biofuel crop. Energycane is a cross of commercial sugarcane (Saccharum officinarum L.) with Saccharum spontaneam L., but unlike sugarcane, it is higher in fiber and lower in sucrose. A similar fact sheet analyzes growing commercial sugarcane for energy (http://edis.ifas.ufl.edu/SC090). This fact sheet provides estimates of costs and returns to sugarcane farmers and determines whether energycane can provide sufficient economic returns to warrant further research into energycane as an energy crop.

\section{Assumption of the Study}

A six-year cycle of energycane is assumed to be grown on a 640 -acre (usually referred to as a "one section") farm. The farm is broken down by section for management decisions. Because the hypothetical farm is already established, there are no development costs to defray. The soil is classified as mineral (sand). There are 16 blocks of 40 acres each. There

1. This is EDIS document SC089, a publication of the Food and Resource Economics Department, Florida Cooperative Extension Service, Institute of Food and Agricultural Sciences, University of Florida, Gainesville, FL. Published August 2011. This publication also is part of the Florida Sugarcane Handbook, an electronic publication of the Agronomy Department, University of Florida, Gainesville, FL. For more information, you may contact the editor of the Sugarcane Handbook, Dr. Ronald W. Rice (rwr@ufl.edu). Please visit the EDIS website at http://edis.ifas.ufl.edu.

2. José Álvarez, emeritus professor, Food and Resource Economics Department, University of Florida, Everglades Research and Education Center, Belle Glade, FL; Zane R. Helsel, courtesy professor, Agronomy Department, University of Florida, Everglades Research and Education Center, Belle Glade, FL, and extension specialist, Department of Plant Biology and Pathology, Rutgers University, New Brunswick, NJ; Florida Cooperative Extension Service, Institute of Food and Agricultural Sciences, University of Florida, Gainesville, FL 32611. The authors would like to acknowledge the contribution of Leslie E. Baucum, Robert Gilbert, Ronald W. Rice, and Fritz M. Roka.

The use of trade names in this publication is solely for the purpose of providing specific information. UF/IFAS does not guarantee or warranty the products named, and references to them in this publication do not signify our approval to the exclusion of other products of suitable composition. 
are 14 ditches 0.5 miles long ( 7 miles total), and 2 one-mile long seepage canals. Total area on roads, canals, and ditches equals 65 acres. Therefore, net acreage equals 575 . The net acreage is equally distributed in 7 parts ( 1 fallow land, 1 plant cane, and 5 stubble crops) of 82 acres each, except for the plant cane acreage, which has 8 acres devoted to seed cane, and the remaining 75 acres to regular production.

\section{Methodology and Data Source}

An enterprise budget was developed with agronomic and cost data, with the objective of estimating production costs and projecting gross and net returns. Data were obtained from several sources: interviews with sugarcane producers, complemented with a recent enterprise budget published by UF/IFAS (Roka, Alvarez, and Baucum 2009), and information on prices, including custom rates charges, provided by local dealers of agricultural inputs and services.

Energycane production for this study is assumed to take place on mineral soils (sand lands) in and around the Everglades Agricultural Area (EAA) not currently being used for sugarcane or other high-value crops. Production potential of these soils is generally lower than the land currently in sugarcane production. Based on preliminary research results and grower opinions, biomass yields from these soils can range from 25 to 35 net tons per acre. We assume a base yield of 30 net tons per acre, per year from a six-year crop cycle (1 plant cane plus 5 ratoon crops). As part of our economic analysis, a range in biomass production from 26 to 34 tons per acre will be considered. A "dry" ton is assumed to be 30 percent of a net ton. Each net dry ton of energycane is assumed to produce 90 gallons of ethanol (Frosch 2008). We assumed in this evaluation of energycane that ethanol would be produced through a process of cellulosic conversion as developed by Dr. Ingram at the University of Florida (Ingram 2009).

\section{Production Costs}

The enterprise budget for energycane is presented in Table 1. Preliminary results show that it costs about $\$ 965$ per year to produce one acre of energycane for energy in a six-year crop cycle. This total cost figure includes variable (\$765) and overhead costs $(\$ 200)$. The break-down of variable costs includes $\$ 6.31$ for fallow land maintenance and $\$ 37.87$ for land preparation. Planting activities account for $\$ 47.34$ per acre. The former costs have been prorated for a six-year crop cycle. All cultural activities performed represent $\$ 309.33$, to which $\$ 82.26$ are added for miscellaneous expenses (assumed 10\% of variable costs) and $\$ 72.39$ for interest of the capital used (8\%) in the previous activities.
Harvesting activities (cutting, loading, and hauling to the mill) total \$210.

The relative magnitude of the total costs associated with energycane production is as follows: fertilizer costs represent 39 percent of the total costs, followed by 36 percent for land preparation and planting, 22 percent for harvesting activities, 21 percent for overhead, and 10 percent for chemical expenses (Table 2). The table from which these percentages were computed shows a sensitivity analysis with increases and decreases by activity at 5 percent intervals.

The stubble replacement decision in energycane production (when to plough out and replant a field) is perhaps the most important economic question facing an energycane grower due to the high cost of replanting. When one considers the total expenses of the planting operation, and not just the prorated cost per year, the overall cost to plant includes $\$ 38$ for fallow land maintenance, $\$ 228$ for land preparation, and $\$ 285$ for planting, for a total of $\$ 551$. The actual cash outlay of the replanting activity represents 57 percent of total costs, hence the importance of extending the crop cycle (i.e., the number of ratoon crops allowed before yields decrease intolerably). Also higher were the fertilizer costs, and as energy prices rise, these will likely continue to be significant costs, thus suggesting that research on nutrient efficiency or alternative sources would have a direct effect on the success of energycane production efforts.

\section{Ethanol from Energycane}

The relative profitability of energycane produced for ethanol at three levels of biomass (and corresponding dry yields), three levels of ethanol prices, and two levels of processing costs ( $\$ 1.65$ and $\$ 1.07$ per gallon of ethanol are believed to encompass the current high and potential low cost) is presented in Table 3. When the processing cost is $\$ 1.65$ per gallon, net returns of $\$ 154$ per acre are obtained with 34 net tons of energycane if the price of ethanol is $\$ 2.90$ per gallon. At that level of processing cost, the other only net returns are $\$ 47$ per acre if 30 net tons of energycane are obtained when the price of ethanol is also $\$ 2.90$ per gallon. More opportunities for positive profitability are shown when the cost of processing ethanol is $\$ 1.07$ per gallon: $\$ 687$ per acre, with 34 net tons of sugarcane and $\$ 2.90$ ethanol price; $\$ 90$ per acre, with 34 net tons of sugarcane and \$2.25 ethanol price; \$517 and \$348 per acre, with 30 and 26 net tons, respectively, at $\$ 2.90$ per gallon of ethanol in both cases.

Break-even prices at different levels of biomass yield (from 25 to 40 net tons per acre) and two processing costs of 
ethanol (\$1.07 and \$1.65) are shown in Figure 1. There is a wide range of potential outcomes. Obviously, the higher the yield and lower the cost of processing ethanol, the lower is the resulting break-even price. Figure 2 shows a comparison between sugarcane and energycane when the processing cost of ethanol is assumed at an average of $\$ 1.35$ per gallon for the energycane and $\$ .50$ per gallon for ethanol processing from sugarcane. In these cases, breakeven prices of ethanol are much lower for ethanol from sugarcane than from energycane.

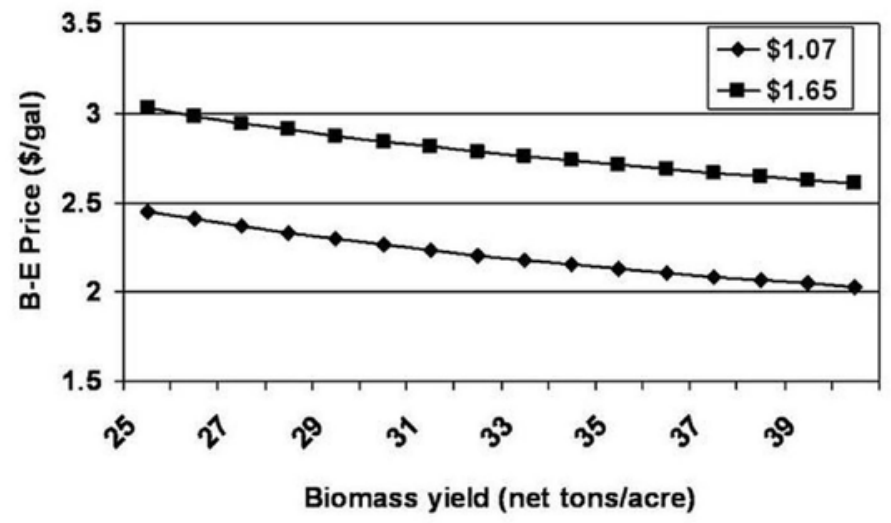

Figure 1. Break-even prices at different levels of yield and two levels of processing cost

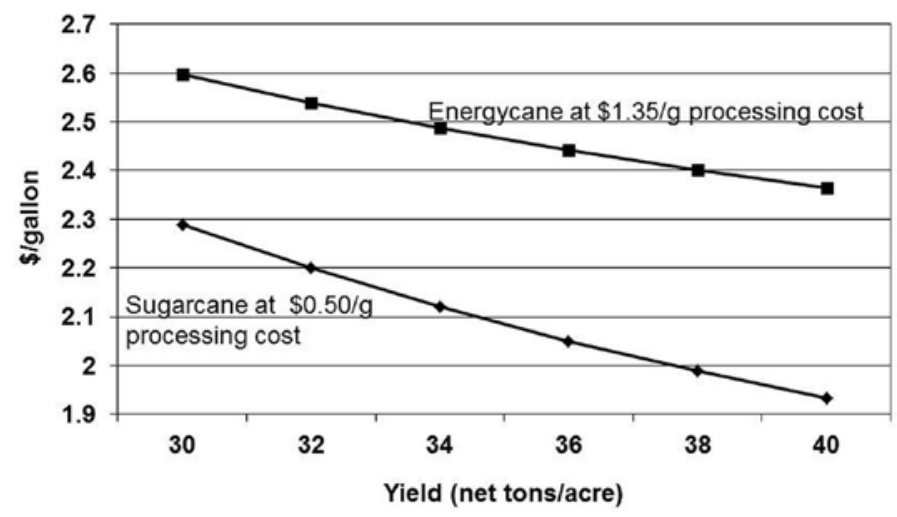

Figure 2. Break-even prices of ethanol from sugarcane and energycane at different levels of yield

\section{Final Considerations}

There is evidence that energycane may become a potentially useful bioenergy crop on the unmanaged mineral soils in south-central Florida. The success of this endeavor will be predicated on UF/IFAS, USDA/ARS, and other partners continuing to develop new energycane varieties with higher biomass and longer-lived stands, and more efficient management practices, particularly fertilizer nutrient inputs, along with the Florida Institute for Sustainable Energy improving the cellulosic ethanol conversion process to lower per gallon processing costs.

\section{References}

Alvarez, José, and Zane R. Helsel. 2011. Economic feasibility of biofuel crops in Florida: Sugarcane on mineral soils. Electronic Data Information Source (EDIS) SC090, University of Florida, Gainesville, FL. http://edis.ifas.ufl. edu/SC090

Collins, Keith. 2007. The new world of biofuels: Implications for agriculture. Energy Information Administration (EIA) Energy Outlook, Modeling, and Data Conference. Office of the Chief Economist, United States Department of Agriculture, Washington, D.C. (March 28). http://www.eia. doe.gov/oiaf/aeo/conf/pdf/collins.pdf

Coyle, William T. 2010. Next-generation Biofuels: Near-term Challenges and Implications for Agriculture. BIO-01-01 Report, Economic Research Service, United States Department of Agriculture, Washington, D.C. (May). http://usda.mannlib.cornell.edu/usda/current/BioEnergy/ BioEnergy-05-14-2010_Special_Report.pdf

Florida Institute for Sustainable Energy. http://www.energy. ufl.edu

Frosch, Brian J. 2008. Estimating and comparing alternative ethanol processes and feedstock sources. Proceedings from the Transition to a Bio Economy Conference, Integration of Agricultural and Energy Systems. Atlanta, GA (February 12-13). http://ideas.repec.org/p/ags/fftrin/48709.html

Ingram, Lonnie. 2009. Cellulosic Biofuels Pilot Plant-Annual Accountability Measures Report. Florida Center for Renewable Chemicals and Fuels, Gainesville, FL. http:// fcrc.ifas.ufl.edu/ FCRC\%20Annual\%20Report\%20July\%20 2008-June\%202009\%20Final.pdf

Roka, Fritz M., José Alvarez, and Leslie E. Baucum. 2009. Projected costs and returns for sugarcane production on mineral soils of south Florida, 2007-2008. Electronic Data Information Source (EDIS) SC087, University of Florida, Gainesville, FL. http://edis.ifas.ufl.edu/SC087 
Table 1. Estimated per acre costs of cultural activities performed on a one-section (640-acre) energycane farm on mineral (sand) soils of southern Florida, 2010

\begin{tabular}{|c|c|c|c|c|c|c|}
\hline Activity & Unit & \# Years & Rate & \# Times & Price & \$/Acre/Year \\
\hline \multicolumn{7}{|l|}{ Fallow land maintenance } \\
\hline Herbicide + surfactant & quart & 1 & 2 & 2 & 7.50 & 30.00 \\
\hline Herbicide application & dollar & & & 2 & 4.00 & 8.00 \\
\hline Total & & & & & & 38.00 \\
\hline Prorated total & & 0.166 & & & & 6.31 \\
\hline \multicolumn{7}{|l|}{ Land preparation } \\
\hline Soil testing and consulting & dollar & 1 & & 1 & 1.11 & 1.11 \\
\hline Disking & dollar & 1 & & 3 & 15.00 & 45.00 \\
\hline Lime (dolomite) application & dollar & 1 & & 1 & 5.00 & 5.00 \\
\hline Lime material & ton & 1 & 1.00 & 1 & 28.00 & 28.00 \\
\hline Laser leveling $^{\text {a }}$ & dollar & 1 & & 1 & 60.00 & 60.00 \\
\hline Calcium silicate slag & ton & 1 & 1.50 & 1 & 56.00 & 84.00 \\
\hline Slag application & dollar & 1 & & 1 & 5.00 & 5.00 \\
\hline Total & dollar & & & & & 228.11 \\
\hline Prorated total & dollar & 0.166 & & & & 37.87 \\
\hline \multicolumn{7}{|l|}{ Planting } \\
\hline All related activities ${ }^{b}$ & $\$ /$ acre & 1 & & 1 & 170.00 & 170.00 \\
\hline Seed cost & $\$$ /acre & & 3.00 & 1 & 25.00 & 75.00 \\
\hline Insecticide ${ }^{c}$ & lb/acre & 1 & 15.00 & 1 & 2.00 & 30.00 \\
\hline Micronutrients $^{d}$ & $\mathrm{lb} / \mathrm{acre}$ & 1 & 20.00 & 1 & 0.51 & 10.20 \\
\hline Total & dollar & & & & & 285.20 \\
\hline Prorated total & dollar & 0.166 & & & & 47.34 \\
\hline \multicolumn{7}{|l|}{ Cultural activities } \\
\hline Nitrogen ${ }^{e}$ & pound & 6 & 44.00 & 4.17 & 0.60 & 110.09 \\
\hline $\mathrm{P} 2 \mathrm{O} 5^{\mathrm{f}}$ & pound & 6 & 50.00 & 1 & 0.60 & 30.00 \\
\hline $\mathrm{K} 2 \mathrm{O}^{\mathrm{g}}$ & pound & 6 & 45.00 & 4.17 & 0.60 & 112.59 \\
\hline Chemical applications & dollar & 6 & 1.00 & 2 & 4.00 & 8.00 \\
\hline Herbicide (pre-emergence) ${ }^{\mathrm{h}}$ & quart & 6 & 3.00 & 1 & 3.00 & 9.00 \\
\hline Herbicide (pre-emergence) & gallon & 6 & 1.00 & 1 & 16.50 & 16.50 \\
\hline Herbicide (post-emergence) ${ }^{i}$ & quart & 6 & 3.00 & 1 & 3.00 & 9.00 \\
\hline Herbicide (post-emergence) & pint & 6 & 2.00 & 1 & 3.00 & 6.00 \\
\hline Oil (surfactant) & quart & 6 & 1.00 & 1 & 1.65 & 1.65 \\
\hline Mechanical cultivation ${ }^{j}$ & dollar & 6 & 1.00 & 1 & 6.50 & 6.50 \\
\hline Total & dollar & & & & & 309.33 \\
\hline Miscellaneous ${ }^{\mathrm{k}}$ & dollar & & & & & 82.26 \\
\hline Interest' & dollar & & & & & 72.39 \\
\hline \multicolumn{7}{|l|}{ Harvesting activities } \\
\hline Harvest, load, and haulm & gross tons & 6 & 30.00 & 1.00 & 7.00 & 210.00 \\
\hline Total variable costs & dollar & & & & & 765.50 \\
\hline \multicolumn{7}{|l|}{ Overhead activities } \\
\hline Supervising and vehicles & gross acre & & & 1 & 10.00 & 10.00 \\
\hline Road and ditch maintenance & gross acre & & & 1 & 5.00 & 5.00 \\
\hline Pumping and water control & gross acre & & & 1 & 40.00 & 40.00 \\
\hline Taxes and assessments & gross acre & & & 1 & 70.00 & 70.00 \\
\hline
\end{tabular}




\begin{tabular}{|c|c|c|c|c|c|c|}
\hline Activity & Unit & \# Years & Rate & \# Times & Price & \$/Acre/Year \\
\hline Land charge & gross acre & & & 1 & 75.00 & 75.00 \\
\hline Total & dollar & & & & & 200.00 \\
\hline TOTAL COSTS & dollar & & & & & 965.50 \\
\hline
\end{tabular}

a Done to one-half of the 82 acres on fallow every year.

${ }^{\mathrm{b}}$ It includes cutting seed cane ( $\$ 30 /$ new planted acre); furrowing, dropping, chopping, and covering ( $\$ 130 /$ acre); and fuel costs provided by the farmer (\$10/planted acre), which equals $\$ 170 /$ planted acre.

c 15 pounds of phorate (Thimet ${ }^{\circledR}$ ) applied in the furrow at plant covering (no application cost is charged).

d 20 pound applied only once during the crop cycle.

e 200 pounds in plant cane in 5 splits; 4 splits of 45 pounds each for each of the 5 stubble crops, for an average of 183.33 pounds per year.

f 50 pounds in plant cane and 50 pounds in the first split in each ratoon crop.

g 225 pounds in plant cane in 5 splits; 4 splits of 45 pounds each for each of the 5 stubble crops, for an average of 187.5 pounds per year.

h Pre-emergence every year: 1 gallon of pendimethalin (Prowl ${ }^{\circledR}$ ) and 3 quarts of atrazine.

i Post-emergence every year: 2 pints of 2,4-D and 3 quarts of atrazine plus 1 quart of oil surfactant.

j One per year.

${ }^{k}$ At $10 \%$ of above variable costs.

${ }^{\prime}$ At $8 \%$ of total variable costs before harvesting.

m Biomass yield assumed in the basic case equals 30 net tons per acre. Since there are no official statistics for Florida's energycane, the figure was adapted from experimental results and grower inputs. Acres harvested per year: $410(82 \times 5)+75=485 / 6=80.83$ 
Table 2. Sensitivity analysis of costs per activity of the basic case (biomass yield of 30 net tons per acre), excluding those belonging in another category to avoid double-counting

\begin{tabular}{|cccccccc|}
\hline Variation & Land Prep & Planting & Fertilizers & Chemicals & Harvest & Overhead & Total \\
\hline $20 \%+$ & 127 & 294 & 450 & 123 & 252 & 240 & 1159 \\
$15 \%+$ & 122 & 282 & 431 & 117 & 242 & 230 & 1110 \\
$10 \%+$ & 117 & 270 & 412 & 112 & 231 & 220 & 1062 \\
$5 \%+$ & 111 & 257 & 394 & 107 & 221 & 210 & 1014 \\
\hline Basic case & $\mathbf{1 0 6}$ & $\mathbf{2 4 5}$ & $\mathbf{3 7 5}$ & $\mathbf{1 0 2}$ & $\mathbf{2 1 0}$ & $\mathbf{2 0 0}$ & $\mathbf{9 6 6}$ \\
$5 \%-$ & 101 & 233 & 356 & 97 & 200 & 190 & 917 \\
$10 \%-$ & 95 & 221 & 337 & 92 & 189 & 180 & 869 \\
$15 \%-$ & 90 & 208 & 319 & 87 & 179 & 170 & 821 \\
$20 \%-$ & 85 & 196 & 300 & 82 & 168 & 160 & 772 \\
\hline
\end{tabular}


Table 3. Relative profitability of energycane produced for ethanol at three levels of biomass yields, three levels of prices of ethanol, and two levels of processing costs

\begin{tabular}{|c|c|c|c|c|c|c|c|c|c|}
\hline \multirow{3}{*}{$\begin{array}{l}\text { Biomass } \\
\text { Yield }^{\mathrm{a}}\end{array}$} & \multirow{3}{*}{$\begin{array}{l}\text { Dry Yield } \\
\text { (ton/acre) }\end{array}$} & \multirow{3}{*}{$\begin{array}{c}\text { Gallon } \\
\text { Ethanol / dry } \\
\text { ton }^{c}\end{array}$} & \multirow{3}{*}{$\begin{array}{c}\text { Price / } \\
\text { Gallon }^{\mathrm{d}}\end{array}$} & \multirow{3}{*}{$\begin{array}{c}\begin{array}{c}\text { Gross } \\
\text { Returns }\end{array} \\
\text { (\$/acre) }\end{array}$} & \multicolumn{3}{|c|}{$\begin{array}{l}\text { Total Costs } \\
\quad(\$ / \text { acre })\end{array}$} & \multicolumn{2}{|c|}{ Net Returns } \\
\hline & & & & & \multirow{2}{*}{$\begin{array}{l}\text { Grower } \\
\text { costs }^{\mathrm{e}}\end{array}$} & \multicolumn{2}{|c|}{ Processing } & \multicolumn{2}{|c|}{ (\$/acre) } \\
\hline & & & & & & $\$ 1.65 / \mathrm{g}^{f}$ & $\$ 1.07 / \mathrm{g}^{\mathrm{g}}$ & $\$ 1.65 / \mathrm{g}$ & $\$ 1.07 / \mathrm{g}$ \\
\hline 34 & 10.2 & 90 & 2.90 & 2662 & 993 & 1515 & 982 & 154 & 687 \\
\hline 34 & 10.2 & 90 & 2.25 & 2065 & 993 & 1515 & 982 & -442 & 90 \\
\hline 34 & 10.2 & 90 & 1.80 & 1652 & 993 & 1515 & 982 & -855 & -323 \\
\hline 30 & 9 & 90 & 2.90 & 2349 & 965 & 1336 & 867 & 47 & 517 \\
\hline 30 & 9 & 90 & 2.25 & 1822 & 965 & 1336 & 867 & -479 & -9 \\
\hline 30 & 9 & 90 & 1.80 & 1458 & 965 & 1336 & 867 & -843 & -374 \\
\hline 26 & 7.8 & 90 & 2.90 & 2036 & 937 & 1158 & 751 & -59 & 348 \\
\hline 26 & 7.8 & 90 & 2.25 & 1579 & 937 & 1158 & 751 & -516 & -109 \\
\hline 26 & 7.8 & 90 & 1.80 & 1264 & 937 & 1158 & 751 & -8322 & -424 \\
\hline \multicolumn{10}{|c|}{ a The basic case plus and minus 4 tons (see Table 1 for sources of data). } \\
\hline \multicolumn{10}{|c|}{${ }^{\mathrm{b}}$ From the assumption of biomass yields with $70 \%$ moisture content. } \\
\hline \multicolumn{10}{|c|}{ ' Figure used the most (Frosch 2008). } \\
\hline \multicolumn{10}{|c|}{ d Calculated from http://e85prices.com/florida.html. } \\
\hline \multicolumn{10}{|c|}{ e Grower costs, taken from Table 1. Harvesting costs adjusted to yields. } \\
\hline \multicolumn{10}{|c|}{$\begin{array}{l}\text { f Total costs, including feedstock, amounts to } \$ 2.65 \text { per gallon; we have deducted the latter to arrive at a processing and capital cost of } \$ 1.65 / \\
\text { gallon (Collins 2007; Coyle 2010: 11). }\end{array}$} \\
\hline \multicolumn{10}{|c|}{$\begin{array}{l}{ }^{9} \text { The United States Energy Department in } 2006 \text { set a goal of reducing production costs for next-generation biofuels to about } \$ 1.07 \text { per gallon } \\
\text { by } 2012 \text {. }\end{array}$} \\
\hline
\end{tabular}

